International Journal of Linguistics, Literature and Translation (IJLLT)

ISSN: 2617-0299 (Online); ISSN: 2708-0099 (Print)

DOI: 10.32996/ijllt

Journal Homepage: www.al-kindipublisher.com/index.php/ijllt

\title{
Nabokov's Art of Translation: Effective Means to Attract a Wide Readership
}

Pinfan Zhu

Professor, English, Texas State University, San Marcos, Texas USA

Corresponding Author: Pinfan Zhu, E-mail: pz10@txstate.edu

\section{ARTICLE INFORMATION}

Received: November 01, 2020

Accepted: December 11, 2020

Volume: 3

Issue: 12

DOI: $10.32996 /$ ijllt.2020.3.12.21

\section{KEYWORDS}

Nabokov, art of translation, rhetorical, translation approach

\section{ABSTRACT}

Vladimir Vladimirovich Nabokov was a great writer who could write in both English and Russian. His novel Lolita shocked the world but still received many praises by critics because of its humor and literary style. However, this article will not discuss his writing talent; instead, it will discuss his art of translation, for Nabokov was also a great translator. Specifically, the article will discuss Nabokov's translation doctrine, translation approaches, and translation tactics (specific ways of tackling translation problems); and how he used them to increase readership. The article focuses on how he increased readership by targeting the audience needs, aiming at conveying complete and accurate meanings, and communicating aesthetic values of the original works.

\section{Introduction}

When one reflects on Lolita, one of the most important novels of the $20^{\text {th }}$ century that shocked readers but still received many critics' praises because of its humor and unique literary style, one naturally thinks of Vladimir Nabokov, a well-known Russian-born American writer who could write both in Russian and English and whose literary style is characterized by complex plots, clever word play, metaphors, detailed description, and use of alliteration. In fact, he was also a good educator. His Lectures on Literature provides insightful advice on how to be good readers and writers (Bower,1980, p. 3), and his “Art of Translation" provides useful information about how to be a good translator and how to create a good translation. Of course, we will not forget his contribution to entomology as an excellent lepidopterist and will be also fascinated by his colorful life careers as an outstanding chess player, tennis coach, a tutor, a metaphysician, a critic, and a translator. Undoubtedly, Nabokov was a man of varied talents and was famous for this reason.

However, this chapter only focuses on his translation talent, which seems to have played an import role in his career as a writer. In fact, he gained his first literary success with his translations of some of Heine's songs. Nabokov translated some famous works from English into Russian such as Alice's Adventures in Wonderland, and from Russian into English such works as Eugene Onegin, by Aleksandr Pushkin, A Hero of Our Time by Mikhail Lermontov, and The Song of Igor's Campaign: An Epic of the Twelfth Century. These translated works adequately reveal Nabokov's mastering skill of translation. So, the author will discuss how Nabokov uses his art of translation to maximize the value of translation, or to gain best results. Specifically, the author will discuss Nabokov's translation doctrine, main approaches, and concrete translation tactics, for these are the very factors that make him a good translator.

\section{Literature Review}

Regarding translation criteria and approaches, scholars of different schools hold different views. The most influential guideline has been the equivalence theory advanced by Eugene Nida who holds that a translator should seek to translate the meaning of the original in such a way that the TL (target language) wording will trigger the same impact (equivalent effect) on the SL (source language) audience as the original wording did upon the ST (source text) audience (Nida \&Taber ,1982). Equivalent theory is more source-text focused without much consideration of the background information of the target language and culture. So, scholars later argued that equivalent effect is impossible to achieve (Qian, Hu,1993), and the success of equivalent effect is only "illusory" (Newmark,1981). As a result, other scholars sought different approaches to the guidelines, such as the discourse approach, cultural approach, hermeneutic approach, and an interdisciplinary approach.

\section{K C AL-KINDI CENTER \\ R D PEVELOPMENT Your gateway to world-closs research}

Published by Al-KindiCenter for Research and Development. Copyright (c) the author(s). This is an open access article under CC BY license (https://creativecommons.org/licenses/by/4.0/) 
However, in this paper the author will not discuss these approaches or which of them is more rational than another. In his opinion, each approach contributes a reasonable and practical solution to the problem from a different perspective. In addition, rarely can a translator stick to one approach in translating a book or a long text. This is because one approach, while appropriate for one type of information or message or a communication situation, may appear very improper for another type of information or another communication situation. So, technical translators need to consider all the approaches as mutually complementary rather than mutually exclusive. In this way, Nabokov set a good example; his way of approaching translation is of a synthetical nature.

\section{Nabokov's Doctrine of Translation}

In his article "The Art of Translation", carried in On Translation edited by Rueben A Brower, Nabokov made this statement:

My main contention was, and is, that the translator, in order to be lucidly faithful to his text, should be aware of this or that authorial reminiscence, imitation, or direct translation from another language into that of the text, and this awareness may not only save him from committing howlers, or from bungling the rendering of stylistic details, but also guide him in the choice of the best wording where several are possible (Brower, 1980, p.97).

On page 101 of the same book, Nabokov also demanded that "English translators will

have to find exact equivalents for such ready-made French locutions in Russian garb..."

In "Problems of Translation: Onegin in English," he claimed that "the clumsiest literal translation is a thousand times more useful than the prettiest paraphrase (Venuti, 2008). All these statements help us to infer that Nabokov's translation norm is more balanced towards achieving equivalent effects since he sought to let his audience get the same effect of the original text from translation, regardless of the subject matter. The equivalence theory is one of the important contemporary translation theories advanced by Eugene Nida, which holds that "The message has to be tailored to the receptor's linguistic needs and cultural expectation, and aim at 'complete naturalness'" (Munday, 2001, p.42). This norm enables him to select translation approaches rhetorically, which we will discuss in the next section. Second, we can also infer that his translation is text and author oriented, which means that, in most cases, he would adopt literal translation. The literal translation approach, which is the opposite to free translation, according to Peter Newmark, is an approach that seeks to find the words that are closest to the target language both in semantic and grammatical aspects (Newmark, 1981, p. 30). Nabokov himself stated clearly that he took literalism to mean accuracy. Then, in "The Art of Translation," Nabokov pointed out three grades of evil in translation which enables us to understand his beliefs about translation:

The first, and the lesser one, comprises obvious errors due to ignorance or misguided knowledge. This is mere human frailty and thus excusable. The next step to Hell is taken by the translator who intentionally skips words or passages that he does not bother to understand or that might seem obscure to vaguely imagined readers; he accepts the blank look that his dictionary gives him without any qualms; or subjects scholarship to primness: he is as ready to know less than the author as he is to think he knows better. The third, and the worst, degree of turpitude is reached when a masterpiece is planished and patted into such a shape, vilely beautified in such a fashion as to conform to the notion and prejudices of a given public. This is a crime, to be punished by stocks as plagiarists were in the shoebuckle days (Bowers,1980, p. 315).

From this passage, it is not difficult to see that Nabokov holds that translation should convey the correct and accurate meanings of the original (Obvious errors due to ignorance and misguided knowledge are regarded as an evil), complete and the actual meanings of the original (skipping words or passages is also an evil), and faithful meanings of the original (planished and patted, vilely beautified masterpieces conforming to prejudiced (biased) notions are an evil as well). These beliefs informed the specific tactics Nabokov took to achieve effective translation. In fact, in " he Servile Path," Nabokov explicitly stated that in translating and annotating Eugine Onegin, "I have sacrificed to total accuracy and completeness of meaning every element of form save the iambic rhythm, the retention of which assisted rather than impaired fidelity" (Brower, 1966, p. 97). Therefore, these statements further confirm my conclusions about Nabokov's principle of translation. But what these conclusions finally mean is that Nabokov's position on translation is more literalists oriented, for translation theorists, according to Peter Newmark, mainly swing between literal and free, faithful and beautiful, exact and natural translation, depending on whether the bias is to be in favor of the author or the reader (Newmark, 1981, p.30). In other words, translation theorists mainly fall into two opposing schools: adaptation school vs. alienation school. 


\section{Methodology}

In studying Nobokov's translation approach, the author mainly uses discourse analysis method and comparison and contrast method. Discourse refers to any instance of language use such as a piece of writing or speech. Discourse analysis aims at studying how language is used in specific situations. A discourse is a collection of one's language uses that reflects his/her style, tone, diction, syntactic preference, preferred language strategies and linguistic idiosyncrasies. Thus, to understand the characteristics of one's language use, an effective way is to use discourse analysis. Since the author explores in this article the translation strategies used by Nabokov for entertaining their audiences, Naturally, discourse analysis becomes his preferred choice. Specific practice includes data collecting, data analysis, and result reporting. To reach this goal, the author read translated works by Nabokov and tried to identify important approaches used by Nabokov and offer my comment on that. Comparison and contrast is the best way to find out the best choice and differences and similarities. The actual way the author takes to do this is to put the translated text in contrast against the original text so see the how effective is the method used by Nabokov. Then the author also compares his translation doctrine with that of other translation theorists to let readers see the differences.

\section{Results and Discussion}

As the representative of the alienation school, Gideon Toury, criticizes the source-text-oriented models of translation, which prescribe aspects of translation in advance, on the basis of the source text, and its environment alone. He emphasizes the importance of the target literary system and advances the concepts of adequacy and acceptability which are two theoretical poles of the continuum in which all translation can be found. These two concepts are widely accepted by the translation circles. To put it simple, Toury emphasizes "adaptation" to the target culture or language in the process of translation so that the TL (target language) audience accepts the version easily. Translation theorists that advocate TL culture-oriented translation are regarded as of the adaptation school.

Contrary to Toury's opinion, Lawrence Venuti (2008) emphasizes the preservation of the original flavor of the source language. So, the view is SL (source language) culture oriented. His theory is anti-translation in nature. He advocates "alienation" in the translation process, which means the alien elements in the SL text should be preserved. The purpose is to let the TL (target language) readers understand and accept the SL culture. Venuti claims openly that he wants to develop a translation theory and practice that go against the dominant trend in which the TL culture is prioritized. It is a new idea to regard translation as cultural communication rather than pure linguistic sign transformation. Translation theorists who advocate SL culture-oriented translation are regarded as of the alienation school (Gentzler,1993).

As we see from the quotes above, Nabokov emphasized the attention to all kinds of authorial elements of the original text, and the lucid faithfulness to the text. So literal approach or faithful approach forms Nabokov's main principles of translation, which is in favor of the author and the literal text of the original (The different terms of faithful, literal, exact, semantic translations, etc. actually mean the same thing about alienation).

Finally, it is also necessary to add that while abiding by the principles of ensuring the complete and accurate meaning, Nabokov also paid attention to convey the aesthetic value of the original. Nabokov is especially noted for his language talent, which is mainly reflected in his clever use of prosodic features, images, metaphors, play on words, parodies, humors, passions, etc. that form the aesthetic value of his language. Naturally, in translation, he will not forget to re-present aesthetic value in his translated works. That is why some of his translated works such as Eugene Onegin, and Alice's Adventures in Wonderland also attract a large number of audiences, and he was able to publish lots of other translated works such as King, Queen, Knave (1968), Mary (1970) and Glory (1971), and his Russian stories from the 1920s and '30s. Now that we understand Nabokov's norm of translation, his main approaches toward translation and beliefs that decides his specific translation tactics, we will discuss how Nabokove followed his doctrine of translation to maximize the value of translation.

\subsection{Discussion of Translation Approaches}

In the author's opinion, Nabokov advocates a rhetorical handling of translation methods. By rhetorical handling of translation approaches, I mean that Nabokov was able to choose the right translation method in light of the type of his audience, the topic of the original text, and the purpose of the original text. A rhetorical situation or a communication situation normally comprises these factors: the writer, the audience, the purpose, and the topic (nature of the text). Only by targeting the needs of these factors can a writer or translator be successful in his/her work. As mentioned in the foregoing paragraphs, different translation theorists prefer different translation approaches; some advocate literal translation while others advocate free translation. But, I would argue that there is no such a problem as to who is right or wrong on the matter. Different communication situations require different norms and approaches. Sticking to either of the norms (literal vs. free) regardless of the rhetorical situation is not advisable. Some texts emphasize the easy acceptance of the intended messages by the readers. Children's stories, operation manuals, and so on fall into this category. Their purposes are to enable the 
audience to understand and accept the translated message in an easy manner so that they can find amusement in the reading or perform certain tasks in light of the translated information. Demanding too much interpretive efforts on the part of the audience will only cause him or her to lose interest in the reading, especially for children, which is not what a translator wants to see. As an outstanding writer, Nabokov was certainly aware of this reality. Just as Julian Moyahan asserts that "Nabokov is a towering figure among modern American novelists... he has shown an entire generation of American writers how to seize reality in its fantastic variety and mystery, and to express their visions of things in boldly imaginative new forms (Roth,1984, p. 17). So, aiming at different audiences, Nabokov was able to choose corresponding translation approaches sagaciously so as to maximize the value or achieve best results of translation. For example, when he was translating Lewis Caroll's Alice's Adventures in Wonderland, which is a famous story for children's reading, he adopted free translation norm. He made many adaptations to accommodate Russian children in his translated Russian version of Alice's Adventures in Wonderland. The most striking example would be the translation of the name Alice in to Anya (Nabokov, 1966) which is the heroine of the story. I consider Anya is an effective translation because the name Anya is popular girl name in Russian language, which means the name creates a nice, lovely, and familiar association in the mind of a Russian child, thus making it easier and more acceptable to him/her. In the "The Servile Path" Nabokov pointed out:

We all know that the popular name of a plant may strike the imagination differently in different languages; its stress maybe on color in one country, and on structure in another; it may have beautiful classical connotations; it may be redolent of unbelievable Floridas; it may contain a honey drop as a residue of the cumulative romantic sense bestowed upon it by generations of elegiasts...(Brower,1966, p. 104).

Though Nabokov seemed to talk about a name of a plant, we can still infer that Nabokov, who had a very critical eye, definitely knew that names, whatever they might be of, had different cultural implications. The use of Anya is just a piece of the right evidence for this. In fact, Leigh Kimmel in his article "Nabokov as Translator," gave several examples of Nabokov's such transformation of English characters into Russian ones to fit into a Russian milieu. The French mouse into a forgotten companion of Napoleon's invasion force is one of the examples. Also, to make some didactic verses Lewis Caroll wrote in the book more acceptable so that they would not lose the humor implied in the verses, Nabokov decided to find pieces of Russian verse which schoolchildren were expected to learn and recite, and then make parodies on them. As pointed out by Kimmel, while most of the early translators of Alice in Wonderland had simply given up on trying to preserve the humor of the puns and simply translated the words as they were, Nabokov instead tried to find pairs of near-homophones in Russian which would be equally humorous for the Russian reader (2). In fact, Nabokov made so many such substitutions that some people even consider the translation a variety of the same theme. All these free translation examples undoubtedly increase the readership among Russian children and help achieve the dynamic equivalent effects among the target audience. This dynamic equivalence is also Nabokov's approach to translation. It might be right to say that free translation may lose some original flavor; however, the lost part might not be easily accepted by children, but the substituted part means more to them in terms of acceptance.

So, the free translation is the right strategy in this case. However, when aiming at a different group of audiences such as people of the scholarly world, Nabokov obviously adopted a different norm, which is literal translation.

Eugene Onegine is one of the classics of Russian literature, and its hero serves as the model for a number of Russian literary heroes. It is a novel in verses characterized by its iambic tetrameter with the unusual rhyme scheme "aBaBccDDeFFeGG", where the lowercase letters represent feminine rhymes while the uppercase letters represent masculine rhymes. The novel is about the afflictions, affections, and fortunes of three young men: Onegin, Lenski, and Pushkin and three ladies. Its events take place between the end of 1819 and the spring of 1825. The scene shifts from the capital to the countryside and thence to Moscow. The description in the novel covers a young rake's day in town; rural landscape and rural libraries; a dream and a duel; various festivities in country and city; and a variety of romantic, satirical, and bibliographic digressions that lend wonderful depth and color to the thing. It has also many references to foreign books and is written in long verse, so the book is obviously written for the scholarly world, and the difficulty of translating the novel is not hard to imagine. However, Nabokov was able to effectively translate the novel by following the literal translation approach. Famous journalist Harrison E. Salisbury had this comment in his book review "Pushkin, Nabokov and Eugene Onegin:"

Mr. Nabokov has not merely rendered the most precious gem of Russia's poetic heritage into limpid, literal poetic translation. He has given Pushkin's wondrous lines the glow and sparkle of their Russian original" (Salisbury 68). 
Literal translation, also called semantic translation by Peter Newmark, is, according to Shengtao Zheng, a Chinese translation theorist, an effective way of preserving the most possible cultural message of the source language sometimes at the sacrifice of the formal elements of the target language and sometimes even at the intelligibility of the target language. Literal translation helps enrich the target language (it may loan words from the source language) and the culture as well (Zheng, 19 54). In fact, Nabokov just wanted his audience to understand the Russian culture and the beauty of Pushikin's language; in a sense, he regarded translation as part of cultural communication; naturally, he found it important to preserve as much as possible of the original cultural message and language features. That is why he made numerous annotations about cultural background in the translated version of Eugene Onegin. On the other hand, readers who read this book are likely to expect to find cultural things about Russia, so they would not be happy to read too much adapted message based on their culture. Then, if they are writers, they would expect to see how a Russian poem is written in terms of prosodic features, rhythms and rhymes. So, it is important to preserve the original language flavor. Therefore, Nabokov's use of literal translation is a clever choice that helps maximize the value of translation in such a case. Here, we look at several such literal translations discussed by Nabokov in his article of "The Servile Path." Evariste Parny (tender Parny as Pushkin calls him in Three, XXIX) in the second piece (La Main) of his Tableaux has the following:

On $n$ edit point: "la résistance

Enflamme et fixe les désires;

Reculons l'instant des plaisirs"

Ainsi parlle un amant trompeur

Et la coquette ainsi raisonne.

La tender amante s'abandonne

A l'object qui touché son Coeur (Brower 107).

Nabokov translated the stanza in a way that helps the reader understand the poetic features of the original stanzas, in addition to their meanings:

One does not say: "resistance

Inflames and fixes the desires;

Let us defer the moment of delights."

Thus speaks the lover who deceives

And the coquette thus reasons.

The tender mistress yields

to the object that affects her heart (Brower 107).

It is not difficult to see that the translated version is very similar to the original language either in form, the number of words in a line, the number of verses in a stanza, the word order (grammatical structure), and even some word forms like resistance, enflame, fixe, coquette, and object. The rhythm is approximate though some rhyming feature is lost. Nevertheless, the imitation of the original style is strongly obvious. Here is another example of how Nabokov communicated the original style in the stanza in which Pushkin imitates Parny:

Кокетка судит хладңокрвңо,

Татьяңа любит не шутя

И предаётся безусловно 
Любви как милое дитя.

Не говорит она: отложим

Люби мы цену тем умножим

Nabokov's translation:

The coquette reasons coolly,

Tatiana in dead earnest loves

And unconditionally yields

To love, like a sweet child.

She does not say let's defer;

Thereby we shall augment love's value (Brower 107).

According to Nabokov, it is very important to reflect Pushkin's imitation tone and synchronize the two sets of terms in Parny and Pushkin. Thus, he chose the English equivalents of the Russian words Кокетка судит, предаётся, апn отложим, which best fit both Parny and Pushkin as we see above. This is obviously a literal translation as it tries to convert both the grammatical structure and semantic elements to the nearest target language equivalents, but it serves to reach the translation purpose here.

Apart from choosing the translation approach in light of the audience type, Nabokov also decided the approach in light of the content. Normally speaking, when the same word means different things in a different milieu, or a stanza is untranslatable, Nabokov would adopt free translation. For example, in "Problems of Translation: Onegin in English," Nabokov rendered " begúnshchim búrnoy cheredóyu s lyukov'yu lech k eyó nogám" as "the waves that ran in turbulent succession to lie down at her feet with love" (Venuti 126). In the original text, two onomatopoeic alliterations begúnshchim búrnoy (the turbulent rush of the surf) and s lyukov'yu lech (the liquid lisp of the waves dying in adoration at the lady's feet) and their literal meanings in the parenthesis are lost in the translation because of their having no corresponding equivalent expressions in English (untranslatability), but the result of the translated version is still good as it is more concise for lines in a stanza and creates an image of a more personified intentional loving act of the waves for the lady. So the lost of the literal meanings brings back a more poetic and romantic image. Another example of free translation can be found in Nabokov's article of "Servile Path" in which Nabokov translated the Russian word акация as a pea tree instead of acasia (the dictionary meaning). He explained that true acasia does not exist in the habitat of the novel but is useful genus of tropical mimosaceous tree. The aкация is actually racemosas that grow throughout the habitat of the novel. It is a yellow flowering Caragana species imported from Asia and grown in gentlemen's bowers along garden allays in northern Russia. Also, Pushkin's line "golden-glistening pea trees" serves to support this (Brower,1966, p.105). Whatever, in translating names of plants, Nabokov advocated that a translator should not take the meaning at its face value (dictionary meaning); instead he needed to find out what the word really means in its contextual habitat, within the terms of a certain imagined place, or in light of certain literary device ( to produce equivalent effect).

This example of acasia serves to explain that when the same name means differently in a different milieu, Nabokov would use free translation. On the whole, handling translation approaches rhetorically in light of the audience type and the nature of the text is one of Nabokov's effective means to maximize the value of translation. He actually demonstrated this feature in his response to "The Strange Case of Pushkin and Nabokov," which was carried in The New York Review of Books of Vol.5 Number 12, 1966. A question from a correspondent alluded to the French rhyme:

Cet animal est très méchant:

Quand on l'attaque, il se defend.

He responded that for the benefit of his learned friends, he had the translation:

This animal is very wicked:

Just see what happens if you kick it. 
Otherwise, he has a fairly close English version:

This beast is very mean:

in fact it will fight back, when it is attacked.

The first translation is freer while the second one is more literal. That is to say Nabokov was always aware of the needs of different audiences and satisfied them accordingly. This the reason why his translation of Eugene Onegin was highly praised, which provides rich annotation so as to preserve the cultural message and original style while trying preserves the rhyme and rhythm so that, without knowing Russian, readers who want to understand Pushkin can also appreciate the poems at a higher level.

\subsection{Accuracy and Completeness}

Accuracy and completeness are also Nabokov's important specific methods (tactics) to maximize the value of translation. Nabokov explicitly stated in his article "The Problem of Translation: Eugene Onegin in English" that he took literalism to mean "absolute accuracy" (125). By looking at a few examples, we will have an idea about how Nabokov achieved accuracy specifically. In Eugene Onegin, Pushkin has literally rendered Chenier 's Une Blanche by Belyanka. Nabokov commented that it would be false literalism for an English translator to render Belyanka ( une blanche) as "a white one" or "a white female" or " fair-faced." The accurate meaning is "a white-skinned female" or "a white girl" (125). Looking at these translated words, we can easily see how the meaning is becoming increasingly accurate with each expression turning more and more specific. And the value of translation is maximized. But to achieve this accuracy, Nabokov definitely had profound understanding of Pushkin's writing style, his education, cultural background and his language idiosyncrasy.

Nabokov's favoring attitude toward accuracy is also reflected in his abhorrence for random, inaccurate, and sloppy translation. In his "The Art of Translation," he condemned the translation done with original meanings distorted according to translators" own taste as big sins and murders. A case of this is found in translating one of Shakespeare's verses "There with fantastic garlands did she come of crowflowers, nettles, daisies and long purples" as "There with most lovely garlands did she come of violet, carnations, roses, lilies" in Russian (317). Nabokov considered this kind of act as "a crime, to be punished by the stocks as plagiarists were in the shoebuckle days" (315). From this view, it is not difficult to imagine how much effort Nabokov spent in achieving accurate translation, and it is also natural to see he received high reviews of his English version of Eugene Onegin. Paying great attention to the shades of meanings is one of Nabokov's means to achieve accuracy. Here is another example of how Nabokov dealt with diction in translating. "Progulki is a word appearing at the beginning of a stanza about Onegin's life on his country estate. Nabokov said, 'It cannot be rendered by the obvious 'walks' since the Russian term includes the additional idea of riding for exercise or pleasure. I did not care for 'promenades' and settled for 'rambles' since one can ramble about on horseback as well as on foot" (Venuti, 2008, p.123). His careful choice of words here works to achieve the best result as he considered both the denotational meaning and connotational meanings in different languages. Ensuring completeness of the original textual meaning is also an important requirement for maximizing the value of translation. Intentional skipping or missing some information in translation only offers partial, misleading, or unintelligible messages to the reader. Thus, Nabokov was also very particular about achieving completeness for his translated messages. He would consider leaving out tricky message a sin. A particular instance he cited from King Lear is the translation of the line "Tray, Blanche and Sweetheart, see, they bark at me" as "A pack of hounds is barking at my heel." He commented that such a translation made "All local color, all tangible and irreplaceable details swallowed by the hounds" implying how inaccurate and unethical the version was (Bower 317). To convey the complete meaning of the original text, one of Nabokov's approaches is to spare no effort in providing detailed annotations. Even for a title of Gogol's Overcoat, he gave supplementary synonyms such as Mantle, Cloak, and She-nel. The purpose is to give the reader a comprehensive understanding of the possible images of this overcoat. His painstaking efforts to provide numerous annotations on information that some would view as secondary serve as evidence that he regarded translation as cultural communication. In "The Servile Path," he emphasized he spent six years translating and annotating Onegin. Small wonder that the reader could appreciate the limpid harmonies with which Eugene Onegin brims, the multiple melodies reverberating through its stanzas, the precise and luminous images, and the unique purity of its Russian diction even without understanding Russian.

On the whole, translation only achieves its maximum value when accuracy and completeness are ensured. Nabokov undoubtedly did an outstanding job in this. He endeavored to make sure that readers received the maximum value from his translations through providing necessary annotations, and made sure no meaning was lost from the original text in the process of translation. 


\subsection{Aesthetic Value}

Ezera Pound, one of the translation theorists, holds that translation should aim at releasing the energy of language, and this energy of language is represented by melopoeia (music property), phonopoeia, (visual property), and logopoeia (the dance of the intellect among words) which are considered also as the aesthetic value of language (Gentzler,1993). So, a translator needs to release this energy in another language or convey the aesthetic value in the target language. This is very true for translating poems, for poems are full of musical properties such as rhythm, rhyme, alliteration, and onomatopoeia; phonopoeic properties such as imagery words, metaphors, and scenes; logopoeic property such as play on words and witty expressions. If a translation of poems does not re-present these features in the original, the reader will not know if he is reading a translated version of a poem or a prose. In such a case, the value of translation is almost lost. Nabokov paid attention to conveying the aesthetic value in his translation. Here is a version of a stanza about a peasant and his horse from Onegin: onomatopoeia

Winter!...the peasant-man re-joicing.

Break the fresh the highway with his sleigh;

His pony, sniffing the new snow

Trots easily along the way (Naboko p.336)

As we can see the fourth line in the stanza rhymes the second, so basically the version keeps the rhyming feature, and is close to the iambic tetrameter of which the Russian poems are typical (the music property). Here is another way of seeing how other aesthetic features are kept. In "The Problem of Translation: Onegin in English" there is such a line in a stanza about a scene where Pushkin were together with a lass: The line reads; “Lesnaya ten',zhurchan'e struy..."(Venuti, 2008) , the words Lesnaya ten means forest shade literally; however Nabokov did not use this version; instead he rendered them as sylvan shade. The translation reflects Nabokov's consideration of creating specific visual property and prosodic feature, for sy/van shade conveys a rustic scene with rich woods, more picturesque, specific, and poetic than the plain word forest. In addition, it forms alliteration with shade, adding acoustic effect to the poem, resulting in more aesthetic value. The word struy means waters and streams respectively, but Nabokov chose streams. The reason I think is that it is easier to conjure up a picture of streams than waters as the latter is a vague word; what is more, streams occur more often in poems as they are more associated with romantic description because they are gentle and more elegant. Also, the word zhurchan, translated as bubbling instead of bubbles creates an onomatopoeia and adds music property to the translation as the sound of bubbling is pleasant to ear and euphonic in a romantic scene. So, Nabokov still created visual property and language beauty in the translation. The line finally now reads: "The sylvan shade, the bubbling of streams..." Definitely, it is a poetic line of aesthetic values as we see images and hear a melody in it. Finally, even in keeping the original rhythmic feet, Nabokov was successful. From Essai, here is an example:

A Bumptious judge, scanning my works, denounces

All of a sudden, with loud cries, a score

Of passages, from so and so translated:

He names their author, and on finding them

Admires himself, pleased with his learning.

Nabokov commented he had translated eleven such pentameters but mostly unrhymed (to save space, I only quoted the first stanza as example). Thus, his awareness of keeping the original rhythms to maximize the music value is obvious. As Nabokov's previous close friend Wilson Edmund points out, a number of later translations which do preserve melody and rhyme have been helped by Nabokov's literal translation (3).

Therefore, trying to maintain the musical properties such as rhyming, rhythm, melody, and onomatopoeia; visual properties such specific images, and metaphors; and logopoeia 
such as witty use of language and play on words are important strategies to maximize the aesthetic value of translation by Nabokov.

\section{Conclusion}

All the foregoing discussions point to the fact that Nabokove mainly abided by the text-oriented translation as his means of achieving accurate and equivalent effects. However, as a translator, he is able to handle the translation approaches rhetorically in light of the audience type, and the type of the text, which greatly increases the readership among his readers though literal translation is his conventional approach. As a means to avoid misleading his audience and providing prejudiced messages so that translation is made easily acceptable to his audience, Nabokov always seeks to communicate complete and accurate meanings of the original to his audience, which is also an effective tactic to maximize the value of translation. Finally, preserving the aesthetic value of the original text so as to give the greatest artistic appreciation to his audience is another Nabokov's translation strategy that maximizes the value of translation. All these lead to his reputation as a famous translator. But still, to be a good translator, we may want to remember the enlightening advice given by this excellent translation master, Nabokov:

In order to be able to give an ideal version of a foreign masterpiece, first of all a translator must have as much talent, or at least the same kind of talent, as the author, as the author he chooses, Second, he must know thoroughly the two nations and the two languages involved and be perfectly acquainted with all details relating to his author's manner, history, and period associations (319).

With my more than 15 years of translation experience, I think this is only too true. But the there is a limitation of this research: more translated works by Nobokov should have been read in order to enhance the credibility of the work.

Translation is more or less like a rhetorical act. It requires a translator to consider the purpose of the translation and the actual needs of the audience. In light of these two requirements, a translator can use skills like amplification (add more explanatory words), abridgement (reduce unnecessary words), conversion (changes among parts of speech),

Adjustment (change the order of the sentence structure), and negation (positive forms expressed in negative forms or vice versa), Nobokov made clever uses of these skills, thus, his translation doctrine is commendable and only by following this doctrine, which can be also named as rhetorical handling of translation, can we greatly increase the marketability and acceptability of our translation.

Funding: The author delares that this research received no external funding"

Acknowledgments: The author declares that this research was individually completed.

Conflicts of Interest: The author declares no conflict of interest. No funder ever participated in any stage of creating this article.

\section{References}

[1] Bower, F. (1980) Vladimir Nabokov: Lectures on literature. New York: Harcourt Brace Jovanovich.

[2] ---- (1981). Vladimir Nabokov: Lectures on Russian literature. New York: Harcourt Brace Jovanovich.

[3] Browers, A. (1966). On Translation. New York: Oxford University Press.

[4] Caroll, L. (1970). Alice's adventures in wonderland (Алиса в стране чудес). Trans. Vladmir Nabokov. Evanston: Northwestern University Press.

[5] Gentzler, E. (1993). Contemporary translation theories. New York: Routledge.

[6] Kimmel, L. (1998, December 20026) Nabokov as translator: An examination of his changing doctrine of translation. http://www.geocities.com/Athens3682/nabokov2.htm

[7] Munday, J. (2001). Introducing translation studies: Theories and applications. New York: Routledge.

[8] Newmark, P. (1981). Approaches to translation. New York: Pergamon Press.

[9] Nabokov, V. (1966) The servile path. On Translation. Ed. Rueben A. Brower. New York: Oxford University Press.

[10] ---- (1980). The art of translation. Vladimir Nabokov: Lectures on Literature. Ed. Fredson. New York: Routledge.

[11] ----- (2002). The problem of translation." The Translation Studies Reader. Ed. Lawreence Venuti. New York: Routledge.

[12] Pushkin, A. (1955). Eugene Onegin: A novel in verse, Trans and Commentary by Vladimir Nabokov, Princeton, NJ: Princeton University Press.

[13] Roth, A. (1984). Critical essays on Vladimir Nabokov. Boston, MA: G.K.Hall \& Co.

[14] Salisbury, H. (1965). Pushkin, Nabokov and Eugene Onegin, Times Literary Supplement, 28 Jan. 68.

[15] Venuti, Lawrence (2008). The translator's invisibility: A history of translation (2nd ed.). Abingdon, Oxon, U.K.: Routledge.

[16] Wilson, E. (1965). Letter, The New York Review of Books. 30:26.

[17] Zheng, S. (1995). Translation \& Cultural Exchanges. People's Press. China. 